Milica Poletanović

Studio za učenje stranih jezika

"Infinitiv“

Beograd, Srbija

milica.poletanovic@gmail.com
DOI: https://doi.org/10.18485/slovenika.2020.6.1.5

UDK: 37.091 .64

$37.091 .3:: 811.163 .6$

$81 ` 243$

Pregledni rad

\title{
Osobenosti udžbenika srodnog jezika kao stranog (na primeru udžbenika za slovenački jezik kao strani)
}

\section{Sažetak}

Udžbenik za učenje slovenačkog kao drugog/stranog jezika Slovenščina brez meja nastao je na osnovu potrebe za savremenim nastavnim materijalom namenjenom govornicima srpskog jezika koji žele brzo i uspešno da savladaju osnove slovenačkog jezika. S obzirom na to da su srpski i slovenački jezik strukturno jako bliski, veoma srodne morfologije i dosta slične sintakse, centralna tema rada je predstavljanje gramatičkih jedinica na lako usvojiv način, kao i maštovito osmišljenih tekstova koji omogućavaju efikasno usvajanje i širenje leksike. Ovim udžbenikom srodnog jezika kao stranog obuhvaćeno je gradivo osnovnog (A1-A2) i početnosrednjeg nivoa (B1) prema Zajedničkom evropskom okviru Saveta Evrope. Udžbenik pored gramatičkih jedinica predstavlja brojne zanimljivosti vezane za slovenačku kulturu, književnost, istoriju, tradiciju i svakodnevni savremeni život.

Ključne reči: slovenački jezik kao strani, udžbenik za učenje stranog jezika, srodnost jezika, L2

Udžbenik možemo definisati kao knjigu koja na sistematičan i učenicima odgovarajući način izlaže građu prema određenom nastavnom planu iz pojedinih predmeta, a udžbenikom se može smatrati svako nastavno sredstvo koje sadrži sistematizovana znanja iz određene oblasti, ali ona moraju biti primerena nivou obrazovanja i uzrastu učenika i didaktički tako oblikovana da doprinose izgradnji učenikovih znanja i veština s obzirom na to da imaju razvojno-formativnu ulogu (Ivić i dr. 2008, 27). Definicije udžbenika podložne su 
promenama vremena, jer je na svoj način i svaki udžbenik delimično odraz toga vremena u kome je nastao, a kako navodi V. Poljak (1984, 10) udžbenik je:

1. osnovna školska knjiga za pojedini predmet za razliku od dopunske i pomoćne literature,

2. pisan je na temelju propisanog nastavnog plana i programa,

3. posebno je didaktički oblikovan, što ostale knjige nisu,

4. učenici ga svakodnevno upotrebljavaju.

U višemilenijskoj istoriji izučavanja stranih jezika s promenama društvenih, ekonomskih, religijskih odnosa u najširem značenju tih termina, te tehnološkim evolucijama i revolucijama, menjali su se kako dominantni (globalni - lingua franca) jezici, tako i pristupi, tehnike i metode jezičkog izučavanja, da bismo se danas, u 21. veku, našli u svetu najsličnijem Makluanovom globalnom selu, gde je zahvaljujući ubrzanim migracijama i razvijenim komunikacjiama dve trećine tog sveta dvojezično ili višejezično. U takvim uslovima se glotodidaktika kao interdisciplinarna nauka sve intenzivnije afirmiše u nastojanjima da kroz objektivna istraživanja spozna mehanizme usvajanja jezika s ciljem da definiše pristupe, operativne, pragmatične komponente koji određuju metode i izvor tehnika i odgovarajućih tehnologija i aplikacija u usvajanju, učenju i nastavi (Vučo 2009, 15). Udžbenici su svakako deo procesa školskog učenja, kao i nastave L2, i shodno tome imaju centralnu funkciju u celokupnom procesu učenja i podučavanja L2.

Od devedestih godina 20. veka naovamo, najviše udžbenika i priručnika za slovenački jezik kao strani izdao je Centar za slovenački kao strani/drugi jezik sa Filozofskog fakulteta Univerziteta u Ljubljani. Reč je pojedinačnim udžbenicima i udžbeničkim kompletima za polaznike svih nivoa kurseva - početnog (A1-A2), srednjeg (B1-B2) i najvišeg (C1-C2) usklađenih sa Zajedničkim evropskim jezičkim okvirom. Pojedini kompleti obuhvataju udžbenik i radnu svesku sa rešenjima vežbi i CD sa audio i video snimcima, dodatno gradivo i priručnik za učitelje, koji je moguće besplatno preuzeti sa sajta Centra za slovenački kao drugi/strani jezik (Spremo 2016, 150). Centar uz obimnu ponudu udžbenika za učenje jezika nudi i zbirke testova za proveru i utvrđivanje usvojenih znanja na svim nivoima, kao i savremene didaktičke dodatke u vidu slikovnih jezičkih kartica za opušteno učenje vokabulara, ilustrovane priručnike, gde su, uz jezik, predstavljene i kulturne osobenosti Slovenije (https://centerslo.si/knjige/ucbeniki-in-prirocniki/). 
Savremeni zahtevi i potrebe zainteresovanih za učenje slovenačkog jezika u Srbiji uticali su na to da se prvenstveno početni kursevi učenja slovenačkog jezika obavljaju u samoj Srbiji. Višegodišnje iskustvo Škole za učenje stranih jezika „Infinitiv“ iz Beograda pokazuje da je polaznicima kurseva za učenje slovenačkog jezika važan motiv učenje od kuće zbog uštede materijalnih troškova boravka u Sloveniji.

Ubrzani privredni razvoj Slovenije poslednjih decenija i viši životni standard, naročito posle ulaska u EU, kako navodi M. Đukanović (2007, 385-390), doveli su do pojačanog interesovanja za učenja slovenačkog jezika kao stranog. Podsećajući na stogodišnju tradiciju izučavanja slovenačkog jezika u Srbiji, autorka takođe ističe da se zainteresovani polaznici danas mogu podeliti u dve grupe - oni koji jezik uče zbog zaposlenja/preseljenja i oni koji ga uče zbog profesionalnog prevođenja. Danas je slovenački moguće učiti i u privatnim školama za učenje stranih jezika, gde se izučava od početnog (A1) do najvišeg (C2) nivoa. Kao rezultat ovih društveno-ekonomskih procesa, u Srbiji je 2014. godine nastao novi udžbenik za učenje slovenačkog jezika kao stranog/drugog Milice Poletanović, Slovenščina brez meja, zasnovan na savremenim lingvodidaktičkim dostignućima i saznanjima, namenjen govornicima srpskog jezika koji bi želeli brzo i uspešno da savladaju osnove slovenačkog jezika i integrišu se u slovenačko društvo. Udžbenik je, zbog velikog interesovanja, 2019. godine doživeo i drugo izdanje.

Učenje stranih jezika, pa i srodnih, spada u kompleksnije procese sticanja znanja, ali i pored toga udžbenici za L2 moraju da ispune brojne uslove - treba istovremeno da poduče, informišu, motivišu i zabave i zato se prilikom njihovog planiranja i same izrade morala obratiti posebna pažnja. Poljak smatra da u strukturi nastavnog segmenta treba da budu zastupljene sve bitne komponente nastavnog procesa: uvođenje u novu temu, izlaganje sadržaja, aktivnosti za sticanje znanja i sposobnosti, ponavljanje sadržaja, proveravanje rezultata (Poljak 1980, 34-50).

Prilikom didaktičkog oblikovanja svih informacija u udžbeniku Slovenščina brez meja primarni akcenat je stavljen na ciljnu grupu kojoj je udžbenik srodnog jezika namenjen (na njenu homogenost, uzrast, predznanje, interesovanje itd.), jer samo takav udžbenik uspeva da omogući napredak ka dostizanju krajnjeg cilja (ka savladavanju osnova slovenačkog kao stranog/drugog jezika). Bugarski tvrdi da jezici mogu biti srodni na više načina, ali se pojam srodstva 
u doslovnom smislu vezuje samo za genetsku povezanost, koja ukazuje na zajedničko poreklo (Bugarski 2003, 67).

Prilikom učenja srodnih jezika neizbežno dolazi do interferencije, tj. do prenosa elemenata jednog jezičkog sistema u drugi jezički sistem, a takav jezički prenos je nekada pozitivan, jer omogućava sporazumevanje već na početnom nivou učenja jezika, a istovremeno može da bude i negativan, jer prilikom prenošenja elemenata iz $\mathrm{J} 1 \mathrm{u} \mathrm{JT/J2} \mathrm{dolazi} \mathrm{do} \mathrm{grešaka,} \mathrm{tj.} \mathrm{odstupanja} \mathrm{od} \mathrm{norme} \mathrm{ciljanog} \mathrm{jezi-}$ ka (Pirih Svetina 2000). Zbog sličnosti sistema takve greške je kod učenja srodnih jezika teško odstraniti $i$, ako im pri učenju ne posvetimo dovoljno pažnje, ostaju trajne (Požgaj Hadži 2000; prema Balažic Bulc 2004, 77-78).

Bitna funkcija ovog udžbenika jeste predstavljanje gradiva uz posebno pripremljene vizualizacije konkretnih problemskih polja, glosara i gramatičkih pregleda, što učenicima omogućava preglednije i jasnije uočavanje i razlika i sličnosti u srodnim jezicima. Paralelno sa tim ispunjava i veoma važnu razvojno-formativnu ulogu $\mathrm{u}$ socio-kulturnom smislu kako $\mathrm{u}$ pogledu na pojedinca, tako i na zajednicu. Dodatak udžbeniku je radna sveska, koja na 98 strana nudi širok spektar zadataka i vežbi sa rešenjima pomoću kojih učenici uvežbavaju nova i ponavljaju ranije stečena znanja iz slovenačkog jezika i kulture. Udžbenikom Slovenščina brez meja obuhvaćeno je gradivo početnog (A1-A2) i početnog srednjeg (B1) nivoa znanja jezika prema Zajedničkom evropskom okviru Saveta Evrope. U okvirima Evrope, ova dva južnoslovenska jezika, slovenački i srpski, prema broju govornika spadaju u male jezike koji su strukturno veoma bliski.

Gramatika i leksika ne mogu se tretirati kao zasebni entiteti, jer leksički izbor uslovljava gramatiku, dakle, oni su u sinergiji bez ograničenja (Schmitt 2007, 14). U udžbeniku su predstavljene osnove gramatike slovenačkog jezika, a izbor gramatičkih jedinica predviđen za navedeni nivo obavljen je na osnovu sledećih kriterijuma: jednostavnosti, važnosti i frekvencije upotrebe, sličnosti i razlike između ova dva srodna južnoslovenska jezika. U udžbeniku se, kako je i uobičajeno, najpre uvode jednostavnije jedinice, jer imaju centralno mesto $u$ jezičkom sistemu. $S$ obzirom na srodnost dvaju jezika pažnja je usmerena na predstavljanje sličnosti i razlika između gramatičkih sistema srpskog i slovenačkog jezika kao srodnih.

Udžbenik sadrži deset poglavlja, svako od njih obrađuje jednu, a najviše tri gramatičke jedinice. 
Tabelarni gramatički pregled sadržaja udžbenika:

\begin{tabular}{|l|l|}
\hline 1. poglavlje & $\begin{array}{l}\text { 1.padež - nominativ (pridev, imenica, zame- } \\
\text { nica), } \\
\text { prezent; }\end{array}$ \\
\hline 2. poglavlje & $\begin{array}{l}\text { 4. padež - akuzativ (pridev, imenica, zame- } \\
\text { nica), } \\
\text { konstrukcija RAD + prezent; }\end{array}$ \\
\hline 3. poglavlje & $\begin{array}{l}\text { 2. padež - genitiv (pridev, imenica, zamenica), } \\
\text { perfekat (pravilni glagoli); }\end{array}$ \\
\hline 4. poglavlje & $\begin{array}{l}\text { 6. padež - instrumental (pridev, imenica, } \\
\text { zamenica), } \\
\text { perfekat (nepravilni glagoli); }\end{array}$ \\
\hline 5. poglavlje & $\begin{array}{l}\text { 5. padež - lokativ (pridev, imenica, zamenica), } \\
\text { futur (pravilni i nepravilni glagoli), } \\
\text { 3. padež - dativ (pridev, imenica, zamenica); }\end{array}$ \\
\hline 6. poglavlje & potencijal (pravilni i nepravilni glagoli); \\
\hline 7. poglavlje & 2. ženska deklinacija (jednina); \\
\hline 8. poglavlje & komparacija prideva; \\
\hline 9. poglavlje & $\begin{array}{l}\text { imperativ, } \\
\text { modalni glagoli; }\end{array}$ \\
\hline 10. poglavlje & svršeni i nesvršeni glagoli. \\
\hline
\end{tabular}

\section{Specifičnosti slovenačke gramatike prikazane u udžbeniku Slovenščina brez meja}

\section{Pismo i glasovi}

Pravilo sa kojim se korisnici udžbenika odmah u prvom poglavlju upoznaju jeste da slovenački jezik koristi samo latinično pismo, a slovenačka abeceda sadrži 25 slovnih znakova. Na kraju prvog poglavlja predstavljena je abeceda tako što je pored svake grafeme navedeno 4 do 5 primera reči koje počinju tom grafemom, jer je predviđeno da student uz pomoć predavača bude upoznat sa pravilima izgovora - pojedina slova i slovne kombinacije slovenačke latinice pokrivaju više glasovnih vrednosti. Uz to, pri izgovornom pisanju reči stranog porekla, prvenstveno vlastitih imena, upotrebljavaju se i druge grafeme (ć, đ, q, w, y itd.), što je takođe navedeno u prvoj lekciji prvog poglavlja. 


\section{Imenice}

Kao osobenost imenica i imenskih reči, navode se dve gramatičke kategorije: postojanje dvojine i nepostojanje vokativa kao posebnog padeža za obraćanje i dozivanje.

Dvojina je jedna od osobenosti slovenačkog jezika. Za razliku od jednine i množine, gramatička kategorija dvojine značenjski je markirana. Dvojinom upućujemo na dve osobe, dva predmeta ili dve pojave, a ne možemo upućivati na neku jedinku ili skup (Đukanović $2005,21)$. U srpskom jeziku ona se očuvala samo u vrlo retkim tragovima. Učenicima kojima je srpski jezik prvi zanimljiva je i činjenica da u slovenačkom jeziku nema vokativa, nego se umesto njega koristi nominativ. Slovenački jezik ima šest padeža, a u odnosu na redosled uobičajen u srpskom u slovenačkom jeziku instrumental i lokativ menjaju mesta (lokativ je peti padež, a instrumental je šesti). Padeži u udžbeniku nisu prezentovani redom kojim se javljaju tadicionalno u gamatikama, nego su predstavljeni na osnovu frekventnosti upotrebe $u$ svakodnevnom jeziku (nominativ, akuzativ, genitiv, instrumental, lokativ, dativ).

Sve gramatičke jedinice su predstavljene i u tabeli, što omogućava lako vizuelno pamćenje, dok su izuzeci od pravila posebno apostrofirani. Uz to, i grafički su posebno naglašeni primeri u kojima dolazi do interferencije - kako bi se izbegle najčešće greške do kojih dolazi usled jezičke sličnosti ova dva jezika.

U prvih pet poglavlja obrađeno je svih šest padeža. Svi su predstavljeni po istom principu zbog lakšeg poređenja i bržeg učenja. Prvo su prikazane tabele sa nastavcima za pridev i imenicu, pored su navedeni primeri upotrebe za sva tri roda, ispod su navedena pravila upotrebe datog padeža, u svakoj lekciji su date i propratne vežbe za samoproveravanje stečenog znanja.

Kod nominativa su posebno istaknuta odstupanja u kojima dolazi do produženja osnove suglasnicima -j-, -t-, -n-, -s-. Pravilo je da većina imenica čija se osnova završava na -r produžuje svoju osnovu suglasnikom -j-; produžetak -t- se javlja kod imenica čija se osnova završava na -e; produžetak -n- imaju imenice čija se osnova zavšrava na -me; produžetak -s- pojavljuje se kod nekoliko imenica, a na osnovnom nivou su predstavljene tri.

Primeri iz udžbenika:

\begin{tabular}{|l|l|l|}
\hline jednina & dvojina & množina \\
\hline slovar & slovarja & slovarji \\
\hline novinar & novinarja & novinarji \\
\hline
\end{tabular}




\begin{tabular}{|l|l|l|}
\hline dekle & dekleti & dekleta \\
\hline ime & imeni & imena \\
\hline drevo & drevesi & drevesa \\
\hline telo & telesi & telesa \\
\hline kolo & kolesi & kolesa \\
\hline
\end{tabular}

Akuzativ je drugi padež koji je obrađen u udžbeniku i kod njega su naglašeni primeri gde dolazi do drugačije i različite upotrebe predloga $N A$ i $U$ u srpskom i slovenačkom.

Primeri iz udžbenika:

\begin{tabular}{|l|l|}
\hline slovenački & srpski \\
\hline $\begin{array}{l}\text { Grem na Dunaj/stranišče/ } \\
\text { dvorišče/obisk/sprehod/vrt. }\end{array}$ & $\begin{array}{l}\text { Idem u Beč/toalet/dvorište/po- } \\
\text { setu/šetnju/baštu. }\end{array}$ \\
\hline Grem v službo. & Idem na posao. \\
\hline
\end{tabular}

U trećem poglavlju je predstavljen genitive, $s$ tim što je u lekciji posebno akcentovano pravilo negacije, tj. da prilikom negiranja $\mathrm{u}$ slovenačkom jeziku koristimo genitiv, a ne akuzativ kao što to propisuje pravilo u srpskom jeziku. Da bi se studentima olakšalo usvajanje ovog pravila, u udžbeniku je predočena komparacija akuzativa i genitiva.

\begin{tabular}{|l|l|l|l|}
\hline & muški rod & ženski rod & srednji rod \\
\hline akuzativ & $\begin{array}{l}\text { Vidim } \\
\text { Tomaža. }\end{array}$ & Poznam Ano. & $\begin{array}{l}\text { Rada imam } \\
\text { mesto. }\end{array}$ \\
\hline genitiv & $\begin{array}{l}\text { Ne vidim } \\
\text { Tomaža. }\end{array}$ & $\begin{array}{l}\text { Ne poznam } \\
\text { Ane. }\end{array}$ & $\begin{array}{l}\text { Nimam rada } \\
\text { mesta. }\end{array}$ \\
\hline
\end{tabular}

Takođe su istaknuti glagoli iza kojih sledi imenica u genitivu, dok u srpskom isti ti glagoli zahtevaju imenice u dativu ili lokativu.

\begin{tabular}{|l|l|}
\hline slovenački jezik & srpski jezik \\
\hline Udeležila sem se tečaja. & Učestvujem na kursu. \\
\hline Veselim se smučanja. & Radujem se skijanju. \\
\hline Razveselila sem se Ane. & Obradovala sam se Ani. \\
\hline
\end{tabular}

U četvrtom poglavlju predstavljene su značajne razlike slovenačkog i srpskog instrumentala: instrumental se u srpskom jeziku koristi sa predlogom i bez predloga (instrumental bez predloga naj- 
češće označava sredstvo, oruđe ili predmet delovanja, a onaj sa predlogom označava društvo), dok u slovenačkom instrumental nikad ne ide bez predloga.

Primeri iz udžbenika:

\begin{tabular}{|l|l|}
\hline slovenački jezik & srpski jezik \\
\hline Ukvarjam se s smučanjem. & Bavim se skijanjem. \\
\hline Plačala sem s kartico. & Platila sam karticom. \\
\hline Vedno potujem z avtom. & Uvek putujem autom. \\
\hline
\end{tabular}

Za razliku od slovenačkog lokativa, koji se bitnije ne razlikuje od lokativa u srpskom jeziku, pažnja u petom poglavlju posvećena je vidnim razlikama dativa u dva pomenuta jezika. U udžbeniku se navode primeri konstrukcija koje zahtevaju upotrebu dativa, a najupadljivija razlika između srpskog i slovenačkog jezika ogleda se u redu reči dva jezička standarda.

\begin{tabular}{|l|l|}
\hline slovenački jezik & srpski jezik \\
\hline Zdi se mi... & Čini mi se... \\
\hline Mudi se mi... & Žuri mi se... \\
\hline
\end{tabular}

\section{Pridevi}

Osmo poglavlje udžbenika bavi se kompracijom prideva i posebno upozorava na pravilo gde se pridevi u slovenačkom jeziku porede opisno, dodavanjem rečce BOLJ/NAJBOLJ ispred pozitiva. Opisna komparacija se javlja kod prideva koji označavaju boje, prideva koji su po poreklu participi, mnogih prideva sa nastavcima -en, -av, -ast, -at.

\begin{tabular}{|l|l|l|}
\hline pozitiv & komparativ & superlativ \\
\hline $\begin{array}{l}\text { slovenački: rdeč } \\
\text { srpski: crven }\end{array}$ & $\begin{array}{l}\text { bolj rdeč } \\
\text { crveniji }\end{array}$ & $\begin{array}{l}\text { najbolj rdeč } \\
\text { najcrveniji }\end{array}$ \\
\hline $\begin{array}{l}\text { slovenački: mrzel } \\
\text { srpski: hladan }\end{array}$ & $\begin{array}{l}\text { bolj mrzel } \\
\text { hladniji }\end{array}$ & $\begin{array}{l}\text { najbolj mrzel } \\
\text { najhladniji }\end{array}$ \\
\hline $\begin{array}{l}\text { slovenački: } \text { utrujen } \\
\text { srpski: umoran }\end{array}$ & $\begin{array}{l}\text { bolj utrujen } \\
\text { umorniji }\end{array}$ & $\begin{array}{l}\text { najbolj utrujen } \\
\text { najumorniji }\end{array}$ \\
\hline
\end{tabular}

\section{Zamenice}

Lične zamenice kao promenljive vrste reči predstavljene su u prvih pet poglavlja udžbenika gde su posebno istaknuti oblici ličnih 
zamenica u nominativu prvog i drugog lica množine. Oblici $M I$ i $V I$ označavaju muški rod, dok za ženski i srednji rod u slovenačkom jeziku postoje oblici $M E$ i $V E$. Već u prvom poglavlju prezentovani su oblici dvojine, gde se kod sva tri lica javlja razlika i u obliku roda:

\begin{tabular}{|l|l|}
\hline slovenački jezik & srpski jezik \\
\hline midva/medve & nas dvoje, nas dvojica / nas dve \\
\hline vidva/vedve & vas dvoje, vas dvojica / vas dve \\
\hline onadva/onidve & njih dvoje, njih dvojica / njih dve \\
\hline
\end{tabular}

U četvrtom poglavlju udžbenika istaknuta je specifičnost slovenačkog instrumentala prvog i drugog lica jednine, kao i lične povratne zamenice, gde postoje po dva oblika sa ravnopravnom upotrebom (menoj/mano, teboj/tabo, seboj/sabo).

\section{Glagoli}

Sistem glagolskih vremena i načina generalno je sličan u srpskom i slovenačkom jeziku. U udžbeniku su od glagolskih vremena i načina predstavljeni prezent, perfekat, futur, potencijal i imperativ.

Posebna pažnja se obraća na buduće vreme glagola BITI, tačnije prosti futur, koji se u srpskom gradi od nenaglašenih, kraćih oblika prezenta pomoćnog glagola HTETI i infinitiva glagola koji se menja. U slovenačkom jeziku glagol BITI u futuru nije složen.

Primeri iz udžbenika:

\begin{tabular}{|l|l|}
\hline slovenački jezik & srpski jezik \\
\hline Jutri bom doma. & Sutra ću biti kod kuće. \\
\hline V sredo bo mrzlo. & U sredu će biti hladno. \\
\hline
\end{tabular}

U šestom poglavlju je naveden potencijal kao složeni glagolski oblik, koji se gradi od aorista pomoćnog glagola BITI i radnog glagolskog prideva, a posebna napomena stavljena je na glagol BITI, čiji je aorist u slovenačkom isti za sva lica (bi), dok u srpskom ima posebne oblike za svako lice (bih, bi, bismo, biste).

Pretposlednje poglavlje udžebnika u gramatičkom smislu posvećeno je modalnim glagolima i u tabeli su prikazani potvrdni i odrični oblici glagola ŽELETI, HTETI, SMETI, MORATI i MOĆI, sa zaključkom da se u slovenačkom iza njih uvek koristi infinitive, dok je u srpskom češća konstrukcija $D A+P R E Z E N T$. Jedini modalni glagol iza koga ne ide infinitiv nego lični glagolski oblik jeste glagol moći (lahko). 
Primeri iz udžbenika:

\begin{tabular}{|l|l|}
\hline slovenački jezik & srpski jezik \\
\hline Smem iti na izlet. & Smem da idem na izlet. \\
\hline Hočem iti na izlet. & Hoću da idem na izlet. \\
\hline Želim iti na izlet. & Želim da idem na izlet. \\
\hline Lahko grem na izlet. & Mogu da idem na izlet. \\
\hline Moram iti na izlet. & Moram da idem na izlet. \\
\hline
\end{tabular}

Udžbenik prati radna sveska sa mnoštvom zadataka, a zadatke prate rešenja koja učeniku omogućavaju samostalno proveravanje pređenog gramatičkog gradiva i zaključivanja do koje je mere usvojio pojedino znanje o nastavnoj temi. Raspored gramatičkih elemenata je i u radnoj svesci prilagođen, precizan i opravdan, a ne slučajan.

\section{Leksika}

Prilikom izbora odgovarajućih reči i izraza (Vučo 1998, 25-40), primenjuju se kriterijumi jezičke i nejezičke prirode. Jezički kriterijumi mogu biti statistički merljivi (frekventnost i distribucija), iskustveni (disponibilnost), zasnovani na semantičkim osobenostima (obuhvatnost) ili na pedagoškim postavkama (savladivost). Nejezički kriterijumi odnose se na potrebe učenika, ciljeve učenja stranog jezika, kao i na uzrast i profil ciljne grupe.

Prateći potrebe i ciljeve učenika i oslanjajući se na prethodno pomenute kriterijume, udžbenik kombinuje izbor leksičkih elemenata prvenstveno vodeći se kriterijumima frekventnosti funkcionalnih reči, tematski uslovljene leksike, dozirajući leksiku postepeno i odmereno.

Kako Đonlaga (2015) navodi u svom magistarskom radu, pozivajući se na Petrovića i Vučo (Petrović 1998, 64; Vučo 1998, 86, 214), broj novih leksičkih jedinica u određenoj didaktičkoj celini nije relevantan, niti je kontrola leksike tako rigorozna kao u početnoj fazi učenja, kada je neophodna restrikcija vokabulara na najfrekventnije i semantički najjednostavnije reči u vezi sa učenicima bliskim pojmovima i situacijama.

Kroz više od 2000 udžbeničkih reči, predstavljenih u deset različitih jezičkih tema, predviđenih za početni nivo učenja stranog jezika učenicima omogućava nesmetanu komunikaciju vezani za razne teme iz svakodnevnog života, poput predstavljanja, putovanja, dijaloga, traženja zaposlenja, karijere, zdravog načina života itd. 
Tabelarni leksički pregled sadržaja udžbenika:

\begin{tabular}{|l|l|l|}
\hline $\begin{array}{l}\text { Poglavlja u } \\
\text { udžbeniku }\end{array}$ & Naziv poglavlja & Tema poglavlja \\
\hline 1. poglavlje & To sem jaz! & $\begin{array}{l}\text { Predstavljanje i } \\
\text { svakodnevni život }\end{array}$ \\
\hline 2. poglavlje & $\begin{array}{l}\text { Sodoben človek nosi } \\
\text { uro, ker je izgubil } \\
\text { čas }\end{array}$ & $\begin{array}{l}\text { Porodica i } \\
\text { provođenje } \\
\text { slobodnog vremena }\end{array}$ \\
\hline 3. poglavlje & $\begin{array}{l}\text { Pripravimo kovčke } \\
\text { za na pot in gremo! }\end{array}$ & Putovanja \\
\hline 4. poglavlje & $\begin{array}{l}\text { Trgovina - moj } \\
\text { drugi dom }\end{array}$ & Kupovina \\
\hline 5. poglavlje & $\begin{array}{l}\text { Darila, darila, } \\
\text { darila... }\end{array}$ & Praznici i proslave \\
\hline 6. poglavlje & V središču mesta & U gradu \\
\hline 7. poglavlje & $\begin{array}{l}\text { Dobra misel - pol } \\
\text { zdravja }\end{array}$ & Zdrav način života \\
\hline 8. poglavlje & $\begin{array}{l}\text { Moški naredi hišo, } \\
\text { ženska dom. }\end{array}$ & Stan/kuća \\
\hline 9. poglavlje & Sodobna družba & Savremeno društvo \\
\hline 10. poglavlje & Za radovedne & $\begin{array}{l}\text { Posebnosti } \\
\text { Slovenije }\end{array}$ \\
\hline
\end{tabular}

U udžbeniku je poklonjena pažnja valjano odabranom konktekstu - ni preteškom ni suviše lakom, a atraktivnom i zanimljivom gde reči nisu izolovane jedinice, nego pripadaju brojnim međusobno povezanim sistemima i nivoima. Tekstovi predstavljeni u udžbeniku pružaju adekvatan uvid u određenu, zadatu tematiku i upoznaju učenike sa odgovarajućim terminima predviđenim za osnovni nivo učenja stranog srodnog jezika. Paralelno sa tim kroz leksički izbor polaznici se uz širenje vokabulara upoznaju i sa običajima, tradicijom i kulturom Slovenije. U pojedinim poglavljima udžbenika Slovenščine brez meja tekstovi su redukovani, svedeni na razumljiv i prihvatljiv nivo učeniku, jer zbog njegove trenutne kompetencije izvorni tekstovi bi otežali uspostavljanje njegovog daljeg jezičkog napredovanja. Tekstovi, posebno na početnom nivou učenja stranog jezika, moraju se prilagoditi, npr. teže reči i sintagme možemo zameniti lakšim, pojednostaviti rečenične strukture, kompleksnije gramatičke primere zameniti jednostavnijim, tj. skratiti tekst (Knez 
2016, 25). Iako bi tekstovi neposredno preuzeti iz medija ili književnih dela korisniku mogli omogućiti bolji uvid u jezičku, diskurzivnu i društvenu autentičnost jezika, oni nisu primereni za udžbenik namenjen početnicima, pa je zbog toga najveći deo tekstualnog materijala Slovenščine brez meja skraćen i adaptiran.

Pri didaktičkom oblikovanju udžbenika Slovenščine brez meja pažnja je posvećena ponavljanju, jer je ono značajno u globalnoj strukturi nastavnog procesa i procesa obrazovanja. Ponavljaju se nastavni sadržaji zbog pamćenja, odnosno trajnosti znanja (Poljak 1980, 45).

Sledeći moderniji koncept udžbeničke literature u priručniku Slovenščina brez meja predstavljaju žanrovski raznoliki tekstovi: narativni, deskriptivni, dijalozi, pesme, proza, pisanje CV-a itd.

\section{Ilustracije}

Na važnost vaspitno-obrazovne funkcije ilustrativnog materijala u udžbenicima za strane jezike ukazali su i autori Končarević (2002, 102-103) i Vujović (2004, 74), prema navodima Mikića (2013, 61), tvrdeći da ovakav materijal olakšava razumevanje tekstova, podstiče na govornu i pisanu produkciju i služi kao sredstvo za evaluaciju postignuća učenika.

Slovenščina brez meja je bogato ilustrovan i moderno dizajniran udžbenik, koji uz gramatičko-leksički sadržaj ima i raznolik likovno-grafički sadržaj pedagoške poruke, počevši od ilustracija, crteža, fotografija, tabela i sl. Ilustracije su jasne, funkcionalne i zanimljive. U udžbeniku se nalazi veliki broj fotografija koje oslikavaju autentične predele Slovenije i njene kulture s ciljem podizanja motivacije učenika za upoznavanjem zemlje i učenjem njenog jezika.

\section{Zaključak}

Udžbenik za učenje slovenačkog kao drugog/stranog jezika Slovenščina brez meja nastao je na osnovu potrebe za savremenim nastavnim materijalom namenjenim govornicima srpskog jezika koji žele da brzo i uspešno savladaju osnove srodnog južnoslovenskog jezika - slovenačkog i kao pionirski poduhvat našao je solidno mesto u udžbeničkoj literaturi. Potvrđuju to i dva njegova dosadašnja izdanja. S obzirom na to da je ovo prvi udžbenik za učenje slovenačkog kao drugog/stranog jezika objavljen u Srbiji posle višedecenijske pauze, a ujedno jedan od retkih udžbenika ove vrste objavljen na nekadašnjem celokupnom srpskohrvatskom govornom području, korisitiće svima koji se zanimaju za savladavanje osnova slovenačk- 
og jezika. Korisniku je ujedno ponuđena i mogućnost za samostalno učenje (samoproveravanje) zahvaljujući rešenjima jezičkih zadataka koji se nalaze na kraju knjige. Zbog kontinuiranog porasta i interesovanja za učenje slovenačkog jezika u Srbiji i nekadašnjim jugoslovenskim republikama, planira se njegova digitalizacija i eventualna dorada za što kvalitetniju upotrebu u duhu vremena i savremenih tendencija u učenju stranih jezika. Udžbenik sa celokupnim gramatičko-vokabularnim sadržajem i osobenostima prikazanim na njegovim stranicama doprinos je i srpskoj i slovenačkoj jezičkoj kulturi i njihovom boljem povezivanju, što je svakako jak motiv učeniku pri učenju novog jezika.

\section{Literatura}

Balažic Bulc, Tatjana. 2004. „Jezikovni prenos pri učenju sorodnih jezikov: (na primeru slovenščine in srbohrvaščine) “. Jezik in slovstvo 49 (3/4): 77-89.

Bugarski, Ranko. 2003. Uvod u opštu lingvistiku. Beograd: Čigoja.

Common European Framework of Reference for Languages: Learning, Teaching, Assessment. 2001. Dostupno na: https://rm.coe.int/16802fc1bf .

Đonlaga, Tanja. 2015. Nastava leksike stranih jezika u osnovnim školama. Magistarski rad. Nikšić: Univerzitet Crne Gore - Filozofski fakultet.

Đukanović, Maja. 2007. „Ko, gde, kada, kako i zašto treba da uči slovenački“. U Savremene tendencije u nastavi jezika i književnosti : zbornik radova, ur. Julijana Vučo, 385-390. Beograd : Ministarstvo za nauku i zaštitu životne sredine.

Đukanović, Maja i Željko Marković. 2005. Osnovi gramatike slovenačkog jezika. Drugo izdanje. Beograd: Leksikom.

Zgodovina Centra za slovenščino kot drugi in tuji jezik $v$ sedmih korakih. Dostopno na: https://centerslo.si/o\%20nas/zgodovina.

Đukanović, Maja. Istorijat učenja slovenačkog jezika na Univerzitetu u Beogradu. Dostupno na http://slovenacki.fil.bg.ac.rs/istorijat.html.

Ivić, Ivan, Ana Pešikan i Slobodanka Antić. 2008. Opšti standardi kvaliteta udžbenika: vodič za dobar udžbenik. Novi Sad: Platoneum.

Knez, Mihaela. 2016. Dopolnilni pouk slovenščine v tujini. Center za slovenščino kot drugi/tuji jezik. Ljubljana: Filozofska fakulteta.

Končarević, Ksenija. 2002. Savremeni udžbenik stranog - ruskog jezika. Struktura i sadržaj. Beograd: Zavod za udžbenike i nastavna sredstva.

Mikić, Jovica. 2013. Korelacija udžbenika i programa u nastavi stranih jezika. Doktorska disertacija. Beograd: Univerzitet u Beogradu - Filološki fakultet. 
Petrović, Elvira. 1998. Teorija nastave stranih jezika. Zagreb: Školska knjiga.

Pirih Svetina, Nataša. 2000. Razvoj jezikovne zmožnosti pri usvajanju slovenščine kot drugega jezika. Doktorska disertacija. Ljubljana: Univerza v Ljubljani - Filozofska fakulteta.

Poljak, Vladimir. 1980. Didaktičko oblikovanje udžbenika i priručnika. Zagreb: Školska knjiga.

Poljak, Vladimir. 1984. Didaktika. Zagreb: Školska knjiga.

Požgaj Hadži, Vesna. 2000. Komunikacijsko-kontrastivni sustav učenja srodnih jezika. Skopje: Filološki fakultet Blaže Koneski.

Schmitt, Norbert. 2007. Vocabulary in Language Teaching. Cambridge: CUP.

Učbeniki in priručniki. Center za slovenščino kot drugi/tuji jezik. Dostopno na: https://centerslo.si/knjige/ucbeniki-in-prirocniki/.

Spremo, Milena. 2016. „Učbeniki, priročniki in učna gradiva za učenje slovenskega jezika za odrasle“. Slovenika: časopis za kulturu, nauku i obrazovanje 2: 149-154.

Vučo, Julijana. 1998. Leksika udžbenika stranog jezika. Podgorica: Univerzitet Crne Gore; Cetinje : Štamparija Obod.

Vučo, Julijana. 2009. Kako se učio jezik - Pogled u istoriju glotodidaktike: od prapočetka do Drugog svetskog rata. Beograd: Ministarstvo za nauku i zaštitu životne sredine: Filološki fakultet.

Vujović, Ana. 2004. Francuska civilizacija u udžbenicima francuskog jezika. Beograd: Zadužbina Andrejević.

Milica Poletanović

Studio za učenje tujih jezikov Infinitiv

Beograd, Srbija

milica.poletanovic@gmail.com

\section{ZNAČILNOSTI UČBENIKA SORODNEGA JEZIKA KOT TUJEGA (NA PRIMERU UČBENIKA ZA SLOVENŠČINO KOT TUJI JEZIK)}

Učbenik za učenje slovenskega kot drugega/tujega jezika Slovenščina brez meja je nastal iz potrebe po sodobnem učnem materialu, namenjenem govorcem srbskega jezika, ki želijo hitro in uspešno osvojiti osnove slovenskega jezika. Glede na to, da sta si srbski in slovenski jezik strukturno zelo blizu, s sorodno morfologijo in mnogimi sintaktičnimi podobnostmi, je glavna tema članka predstavljanje lahko osvojljivih slovničnih enot in domiselnih besedil, ki omogočajo učinkovito usvajanje in širjenje leksike. Učbenik sorodnega jezika kot tujega po Skupnem evropskem okviru Sveta Evrope obsega gradivo za osnovno (A1-A2) in začetno srednjo raven (B1). Poleg slov- 


\section{Poletanović \\ Osobenosti udžbenika srodnog jezika...}

ničnih enot učbenik predstavlja tudi številne zanimivosti, povezane s slovensko kulturo, književnostjo, zgodovino, tradicijo in sodobnim vsakdanjim življenjem.

Ključne besede: slovenski jezik kot tuji, učbenik za učenje tujega jezika, sorodnost jezikov, L2

Milica Poletanović

Foreign Language Studio Infinitiv

Belgrade, Serbia

milica.poletanovic@gmail.com

\section{FEATURES OF TEXTBOOKS FOR SIMILAR LANGUAGES AS FOREIGN LANGUAGES (EXAMPLE OF TEXTBOOK FOR SLOVENIAN LANGUAGE AS FOREIGN LANGUAGE)}

Textbook for learning the Slovenian language as a second/foreign language, Slovenščina brez meja, was created in pursuit of a need for a modern teaching material for the speakers of Serbian that wish to learn the basics of Slovenian quickly and successfully. Considering the fact that the Serbian and Slovenian languages are similar in structure, with related morphology and pretty similar syntax, the central portion of the paper is representing grammatical units in a manner that is easily adoptable, as well as imaginative texts that enable efficient adoption and expansion of the vocabulary. This textbook of a similar language as a foreign language includes lessons of the beginning (A1-A2) and beginning and medium level (B1) in line with the Common European Framework of the Council of Europe. In addition to grammatical lessons, the textbook includes a number of interesting topics related to the Slovenian culture, literature, history, tradition and modern way of living.

Key words: Slovenian as a foreign language, foreign language textbook, language similarities, L2

Primljeno / Prejeto: 14. 06. 2020.

Prihvaćeno / Sprejeto: 04. 12. 2020 